\title{
Financial instability as a sustained export growth limiting factor of the Russian far east regions
}

\author{
Vilena Yakimova* \\ Amur State University, Ignatievskoe Str., 21, 675027 Blagoveshchensk, Russia
}

\begin{abstract}
The paper analyses the export dynamics of the Russian Far East regions in the context of cyclical business activity. A multi-regression model with lag variables is formed during correlation-regression analysis, since a tendency for a lagging export reaction in response to fluctuations in financial instability indicators was revealed. The analysis showed that exports are influenced by factors of economic activity, fluctuations in real exchange rates, oil prices and levels of external debt relative to GDP. During the crisis, there was a short-term pattern of growth, but in the subsequent period, the decline in the output of exporters, the shortage of financial resources, the increase in the cost of materials and other costs led to a reduction in the sales of products for export. Financial instability is becoming the main source of financial risk for exporters, requiring regional government intervention and business support mechanisms.
\end{abstract}

\section{Introduction}

The strategy of sustainable growth of the Russian Far East regions caused by the development of export potential due to the advantageous geographical location and proximity to the countries of Asia and the Pacific Primorsky, Khabarovsk Territories, as well as the Amur and Jewish Autonomous Regions have a border position. At the same time, the authorities and business support institutions in the macro-region are implementing active incentive policies aimed at inflow of investment in export-oriented production, reduction of administrative barriers, subsidizing the costs of certification and transportation of products for export. The economists Kahouli, Kadhraoui [1], Rahman [2], Bennett [3] see exports as catalysts for sustainable regional economic growth, and geographical proximity and availability of transport and logistics infrastructure, institutional, financial and economic factors as determinants of the investment attractiveness of territories [4]. Agglomeration and resource concentration processes, industrial base, location within the territory become key factors in the spatial location of exporters [5].

The attraction of long-term investment in the export activities of economic agents is associated with cyclical fluctuations, which periodically occur at the macro level and become constraints on the sustained growth of the economy. Financial instability and business-cycle transitions have become a contemporary problem, which is explored in the

${ }^{*}$ Corresponding author: vilena_yakimova@mail.ru 
academic literature. P. Pascal [6] describes the model of how financial crises interact with borrowing and investment. Eero Tölö [7] developed logistic regression models and neural networks to predict systemic financial crises. Financial crises are predicted through stock index fluctuations [8]. Crisis forecasting is now relevant due to the spread of coronavirus infection (COVID 19) and falling oil prices [9].

A study of the crisis impact on export volumes is an important objective for the adoption of anti-crisis measures to reduce the impact of shocks on the financial sustainability of exporters. In a context of financial stability, exporters ensure greater output growth through sufficient and equitable use of financial resources and effective capital accumulation and augmentation. Under conditions of sustainability, a favorable business and investment climate, stable and permanent ties with foreign partners are being created, and the range of products and foreign markets are being expanded. The main indicators, describing the evolution and export structure of the Russian Far East regions, are presented in Table 1.

Table 1. Descriptive export statistics of the Russian Far Eastern regions for 2006-2020.

\begin{tabular}{|l|c|c|c|c|c|c|}
\hline $\begin{array}{c}\text { Far Eastern Federal } \\
\text { District region }\end{array}$ & $\begin{array}{c}\text { Average } \\
\text { value, } \\
\text { million } \\
\text { US } \\
\text { dollars }\end{array}$ & $\begin{array}{c}\text { Standard } \\
\text { deviation, } \\
\text { million US } \\
\text { dollars }\end{array}$ & $\begin{array}{c}\text { Share of the Far } \\
\text { Eastern Federal } \\
\text { District region } \\
\text { exports, }\end{array}$ & $\begin{array}{c}\text { Asym } \\
\text { metry }\end{array}$ & $\begin{array}{c}\text { Excess } \\
\text { kurtosi } \\
\text { s }\end{array}$ & $\begin{array}{c}\text { Variati } \\
\text { on } \\
\text { coeffici } \\
\text { ent }\end{array}$ \\
\hline Sakhalin Region & 11667.8 & 4539.19 & 47.41 & -0.8 & 0.4 & 0.39 \\
\hline Republic of Yakutia & 307.9 & 178.7 & 14.35 & -0.3 & -1.4 & 0.58 \\
\hline Primorsky Territory & 2332.8 & 1097.65 & 11.94 & 0.16 & -1.4 & 0.47 \\
\hline Khabarovsk Territory & 11667.8 & 4539.19 & 7.57 & -0.8 & 0.4 & 0.39 \\
\hline Republic of Buryatia & 810.1 & 399.29 & 4.87 & 0.3 & -0.9 & 0.49 \\
\hline Trans-Baikal Territory & 335.3 & 230.2 & 4.38 & 2.5 & 6.7 & 0.69 \\
\hline Kamchatka Territory & 563.4 & 236.45 & 3.44 & -0.8 & -0.18 & 0.42 \\
\hline Amur Region & 329.7 & 111.95 & 2.13 & -0.08 & -1 & 0.34 \\
\hline Magadan Region & 307.9 & 178.70 & 1.90 & -0.3 & -1.4 & 0.58 \\
\hline $\begin{array}{l}\text { Chukotka Autonomous } \\
\text { District }\end{array}$ & 89.7 & 69.73 & 1.19 & 1.4 & 3.5 & 0.78 \\
\hline $\begin{array}{l}\text { Jewish Autonomous } \\
\text { Region }\end{array}$ & 61 & 61.69 & 0.84 & 1.5 & 0.9 & 0.99 \\
\hline $\begin{array}{l}\text { Russian Far Eastern } \\
\text { regions export }\end{array}$ & 21932.2 & 6959.34 & 100 & -0.55 & -0.93 & 0.32 \\
\hline
\end{tabular}

Exports from the Russian Far Eastern regions are commodity-based, with a traditionally high share of exports going to regions with a developed mining industry (Sakhalin region and Yakutia). At the same time, border regions are not leading because of less developed productive capacities. Exporters of the Amur Region, Khabarovsk and Primorsky Territories belong to medium and small businesses specializing in agriculture, forestry and manufacturing. Indicators of variation and asymmetry show the degree of export volume instability from 2006 until the present day. On average, the variability of Russian Far East exports can be estimated as moderate (32\%), but in many regions there is a high level of volatility (rapid growth in some periods and sharp drop) - Chukotka Autonomous Region, Jewish Autonomous Region, Trans-Baikal and Primorsky Territories, Yakutia, etc. Due to these trends, it seems necessary to determine the influence of business cycles on the export volume instability, both for the macro-region as a whole and for the specific territories.

\section{Methods and economic variables}

Econometric analysis methods are chosen to identify the impact of financial instability on export movements. Statistical indicators of variability describe the degree of stability and responsiveness to shocks and macro-changes. With increasing dissipation and deviation 
from average values, the risk of a decline in exports increases with unfavorable changes in stock and currency markets. The most commonly used indicators of financial instability are selected as variables [10]. These include: Balance of payments (net lending) ( $\left.\mathrm{X}_{1}\right)$; GDP as an indicator of economic activity $\left(\mathrm{X}_{2}\right.$; Dollar nominal and real exchange rates $\left(\mathrm{X}_{3}\right)$; Ruble real effective exchange rate index and US dollar to ruble exchange rate $\left(\mathrm{X}_{4}-\mathrm{X}_{5}\right)$; RTS stock index $\left(\mathrm{X}_{6}\right)$; Brent oil price $\left(\mathrm{X}_{7}\right)$; interest rates on enterprise credit $\left(\mathrm{X}_{8}\right)$; Russian Gold Reserves $\left(\mathrm{X}_{9}\right)$; Russian external debt-to-GDP ratio $\left(\mathrm{X}_{10}\right)$.

The method used in the analysis is distributed lags method. To form a regression model, it is assumed that exports respond to changes in performance over time. It is therefore recommended to include lag variables $\left(\mathrm{X}_{\mathrm{i}-1}\right)$ in the model.

For the analysis, the model (1) was chosen:

$$
\operatorname{Exp}=b_{0}+b_{1} X_{1}+b_{2} X_{2}+. . b_{i} X_{i} .
$$

where $b_{0}$ is the free term of the model, $b_{i}$ is the coefficients of multiple regression, and $\mathrm{X}_{\mathrm{i}}$ is the indicators of financial instability.

A model with lag variables has the form:

$$
\operatorname{Exp}_{t}=b_{0}+b_{1} X_{t-1}^{1}+b_{2} X_{t-1}^{2}+\ldots b_{i} X_{t-1}^{i}
$$

where $\operatorname{Exp}_{t}$ is the exports volume at the moment of time $t$ (lagging variable), $\mathrm{X}_{\mathrm{t}+1}^{\mathrm{i}}$ is the $\mathrm{i}$-th indicator of financial instability at the moment of time (t-1).

The model was validated using Fisher's F-criterion and Durbin-Watson t-statistics. The model is tasted for autocorrelation of time series and justification of lag selection. Testing the model for multicollinearity for models with lag variables allows selecting the most appropriate model. The model can be constructed and tested by a step-by-step analysis in the SPSS program. Step-by-step analysis allows to compare models without lag variables and with their inclusion.

\section{Model and Discussion}

Periods of macroeconomic financial instability during 2008-2020 are characterized by the nature, causes, duration and degree of influence on productive and export activities of enterprises in the real economy. Table 2 presents the estimated indicators of financial instability selected as indicators.

Table 2. Descriptive statistics of financial instability factors for 2006-2020.

\begin{tabular}{|l|c|c|c|c|c|}
\hline \multicolumn{1}{|c|}{ Indicator } & $\begin{array}{c}\text { Avera } \\
\text { ge }\end{array}$ & $\begin{array}{c}\text { Standard } \\
\text { deviation }\end{array}$ & $\begin{array}{c}\text { Asym } \\
\text { metry }\end{array}$ & $\begin{array}{c}\text { Excess } \\
\text { kurtosis }\end{array}$ & $\begin{array}{c}\text { Variation } \\
\text { coefficien } \\
\text { t }\end{array}$ \\
\hline $\begin{array}{l}\text { Balance of payments (net lending), } \\
\text { bln. US dollars }\end{array}$ & 61 & 31 & 0.3 & -1.1 & 0.52 \\
\hline $\begin{array}{l}\text { Indicator of economic activity (GDP), } \\
\text { bln. US dollars }\end{array}$ & 70447 & 28690 & 0.02 & -1.2 & 0.41 \\
\hline Nominal dollar to ruble exchange rate & 44 & 18.3 & 0.5 & -1.6 & 0.42 \\
\hline RTS stock index & 1351 & 448.5 & 0.28 & 0.08 & 0.33 \\
\hline Brent oil price & 76.4 & 23.3 & 0.4 & -1.33 & 0.31 \\
\hline $\begin{array}{l}\text { Interest rates on loans to small and } \\
\text { medium-sized businesses, \% }\end{array}$ & 11.6 & 2.4 & 0.3 & -0.96 & 0.21 \\
\hline Gold Reserves, bln. US dollars & 457 & 78.1 & -0.15 & -0.24 & 0.17 \\
\hline External debt to GDP ratio, \% & 32 & 4.3 & 0.6 & -0.7 & 0.13 \\
\hline
\end{tabular}


Macroeconomic indicators do not fluctuate much compared to export volatility, but the nominal value of the dollar, the RTS stock index and GDP vary moderately. There has been a steady increase in the value of the dollar against the ruble and in interest rates. Economic imbalances in certain periods caused exports of the Russian Far East regions to fall (Figure $1)$.

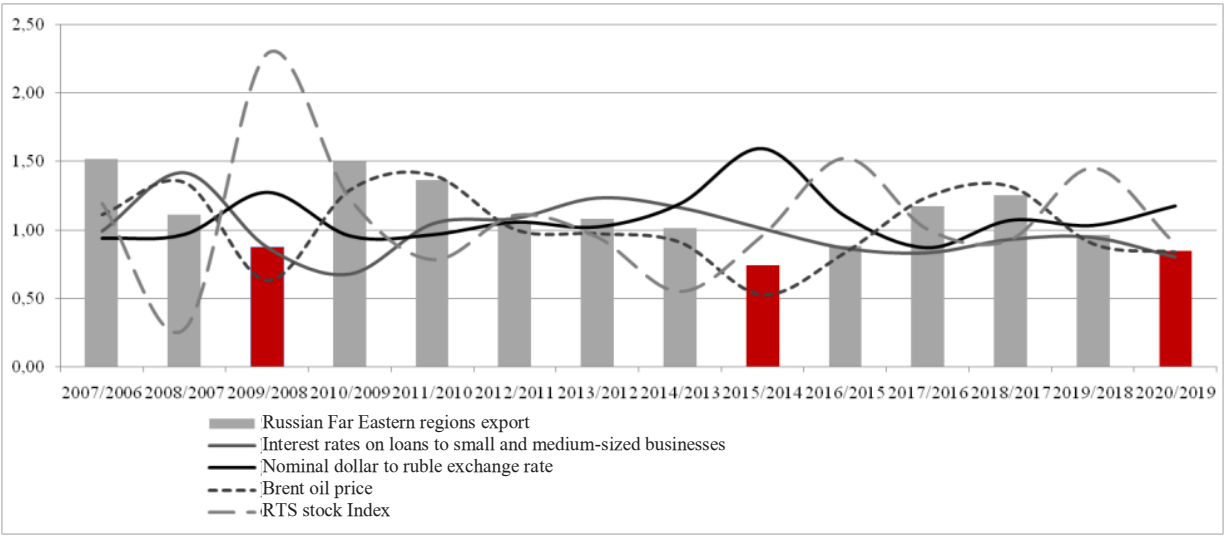

Note: red lines refers to periods of falling exports as a result of financial instability.

Fig. 1. Changes in the export volume of the Russian Far East regions in the context of financial instability

The economic crisis of 2008-2009 had the greatest adverse impact on the business sector of the economy, as the effects of imbalances led to higher borrowing costs and stock market instability. The graph shows that during periods of economic recession production is declining and exports are falling.

In 2009, the increase in the Bank of Russia's refinancing rate to $13 \%$ triggered an increase in credit rates and risks of exporters. Interest-rate risks caused by rate volatility have increased the cost of debt service, debt dependency of enterprises and reduced the investment profitability of projects. The 2014-2016 crisis was caused by cyclical oil price fluctuations and Russian sanctions.

The impact of factors on exports of the Far East was significant, owing to the high volatility of the exchange rate and the instability of the banking system. The decline in investment in commodity exports was caused by the double devaluation and the loss of business interest in foreign markets. In 2020, similarly, exports fell by $15 \%$ compared to 2019 , which was caused by a decline in economic activity due to the spread of coronavirus infection in all countries. In general, the Ministry of Economic Development of the Russian Federation assesses the impact of unfavorable epidemiological situation on export volumes as insignificant, since in mid-2020, a recovery period was observed and measures were taken for investment support for non-resource exports. The factoring model for exports of the Russian Far Eastern regions can be described with lag variables:

$$
\operatorname{Exp}_{t}=-39760+0,29 X_{t+1}^{2}-210 X_{t+1}^{5}+230 X_{t+1}^{7}+709_{t+1}^{10}
$$

Insignificant factors are excluded from the original variables in order to eliminate the influence of autocorrelation and multicollinearity. The testing of $\mathrm{F}$ and t-criterion showed the chosen model validity $\left(\mathrm{R}^{2}=0,96\right)$.

The model describes the dependence of exports on the growth of GDP, oil prices and the growth of external debt to GDP, the decrease as a result of the growth of the real exchange rate of the US dollar to the ruble. The impact of GDP is caused by the dependence of exports on the general trend of production and business activity of the 
enterprise sector in all branches of the economy. Exports respond to changes in oil and coal prices on the world market. The reason for the influence of this factor is the large share of crude oil, natural gas, coal exported to the Asia-Pacific region in the export structure of the Sakhalin region. Real exchange rates are indicators of macroeconomic instability under conditions of inflation. An increase in the foreign exchange rate stimulates export growth, as market competition in foreign markets weakens. The unfavorable pattern of foreign exchange fluctuations and the impact on the decline in exports in times of crisis are caused by a reduction in the demand for products and the output of enterprises operating in unstable economies, the decline in profits and profitability as a result of the increase in the cost of servicing loans and credits, and the cost of purchasing imported materials and equipment. Inflationary expectations and the motivation of entrepreneurs to maintain capital in a risk averse environment play an important role.

\section{Conclusions}

1. The Russian Far East regions, which have a high export potential, are not achieving sustained growth due to their unstable export performance and raw material orientation. Distortions and imbalances in the stock, banking and business sectors are becoming threats to financial stability in the real economy.

2. Exporters in times of crisis are unable to cope on their own with credit, interest, foreign exchange, liquidity and financial stability risks. There are problems in selling products on foreign markets and in ensuring the sustainability of exporters.

3. A factor model reflecting the dependence of Russian Far East exports on financial instability has shown the influence of factors on exports: GDP, oil prices, external debt to GDP and the US dollar to the ruble exchange rate. Sharp fluctuations in factors can signal a drop in exports next year, therefore, a timely balanced macroeconomic and regional policy can create conditions for reducing the impact of macroeconomic shocks. 4. The resulting factor model describes the relationships between the indicators, takes account of lag variables but needs to be improved by assessing non-linear relationships between variables, introducing structural indicators and taking into account the sectoral specialization of regions. A study of the impact of financial instability on regional exports is possible in the future to assess financial risks and develop stress testing techniques for exporters.

\section{References}

1. B. Kahouli, N. Kadhraoui, Int. J. Euro-Mediterr. Stud., 5 (2012)

2. M. M. Rahman, E. Velayutham, Renewable Energy, Elsevier, 147 (2020)

3. D. L. Bennett, Journal of Business Venturing, 5 (2019)

4. S. V. Pankova, V. A. Yakimova, Smart Innovation, Systems and Technologies, 172 (2020)

5. J. M. Nazarczuk, S. Umiński, T. Brodzicki, Ann RegSci, 64, (2020)

6. P. Pascal, Journal of Economic Dynamics and Control, 112 (2020)

7. Eero Tölö, Journal of Financial Stability, 49 (2020)

8. Doobae Jun, Changmo Ahn, Jinsu Kim, Gwangil Kim, Physica A: Statistical Mechanics and its Applications, 526 (2019)

9. I. V. Kosorukova, A. A. Bratanov, Property Relations in the Russian Federation, 7 (2020)

10. M. G. Tiunova, Theory and Practice, 4 (2018) 